\title{
Temperature fluctuations in a warmer environment: impacts on microbial plankton
}

\author{
Marco J. Cabrerizo (iD ${ }^{1,2^{*}} \quad$ Emilio Marañón (iD 1,2 \\ ${ }^{1}$ Departamento de Ecología y Biología Animal, Universidade de Vigo, Facultad de Ciencias del Mar, Campus Lagoas Marcosende s/n, 36310 Vigo, Spain \\ ${ }^{2}$ Centro de Investigación Mariña da Universidade de Vigo (CIM-UVigo), Illa de Toralla s/n, 36331, Vigo, Spain
}

\begin{abstract}
Warming can cause changes in the structure and functioning of microbial food webs. Experimental studies quantifying such impacts on microbial plankton have tended to consider constant temperature conditions. However, Jensen's inequality (or the fallacy of the average) recognizes that organism performance under constant conditions is seldom equal to the mean performance under variable conditions, highlighting the need to consider in situ fluctuations over a range of time scales. Here we review some of the available evidence on how warming effects on the abundance, diversity, and metabolism of microbial plankton are altered when temperature fluctuations are considered. We found that fluctuating temperatures may accentuate warming-mediated reductions in phytoplankton evenness and gross photosynthesis while synergistically increasing phytoplankton growth. Also, fluctuating temperatures have been shown to reduce the positive warming effect on cyanobacterial biomass production and recruitment and to reverse a warming effect on cellular nutrient quotas. Other reports have shown that fluctuations in temperature did not alter plankton responses to constant warming. These investigations have mostly focused on a few phytoplankton species (i.e. diatoms and haptophytes) in temperate and marine ecosystems and considered short-term and transient responses. It remains unknown whether the same responses apply to other species and ecosystems and if evolutionary change in thermally varying environments could alter the magnitude and direction of the responses to warming observed over short-term scales. Thus, future research efforts should address the role of fluctuations in environmental drivers. We stress the need to study responses over different biological organization and trophic levels, nutritional modes, temporal scales, and ecosystem types.
\end{abstract}

\section{Keywords}

Aquatic ecosystems, global change, interactive effects, natural variability, thermal dependence

\section{Peer Review}

The peer reviewers who approve this article are:

1. Martin J Kainz, WasserCluster - Biologische Station Lunz, Inter-University Center for Aquatic Ecosystems Research, Lunz am See, Austria

Competing interests: No competing interests were disclosed.

2. Dedmer van de Waal, Department of Aquatic Ecology, The Netherlands Institute of Ecology, The Netherlands Competing interests: No competing interests were disclosed. 
*Corresponding author: Marco J. Cabrerizo (marcojc@uvigo.es)

Competing interests: The authors declare that they have no competing interests.

Grant information: This work was supported by projects Responses of marine phytoplankton to environmental variability across multiple levels of biological organization (POLARIS, PGC2018-094553-B-I00) from the Spanish Ministerio de Ciencia, Innovación y Universidades (MICINN) to EM and Tropical and South Atlantic: climate-based marine ecosystem prediction for sustainable management (TRIATLAS, Grant No. 817578) from the European Union's H2020 research and innovation programme. MJC was supported by Juan de la Cierva-Formación (FJCI2017-32318) and Incorporación (FJCI2019-040850-I) grants from MICINN.

The funders had no role in study design, data collection and analysis, decision to publish, or preparation of the manuscript.

Copyright: (C) 2021 Cabrerizo MJ et al. This is an open access article distributed under the terms of the Creative Commons Attribution License, which permits unrestricted use, distribution, and reproductison in any medium, provided the original work is properly cited.

How to cite this article: Cabrerizo MJ and Marañón E. Temperature fluctuations in a warmer environment: impacts on microbial plankton. Faculty Reviews 2021 10:(9) https://doi.org/10.12703/r/10-9

Published: 29 Jan 2021, Faculty Reviews 10:(9) https://doi.org/10.12703/r/10-9 


\section{Introduction and context}

Microbial plankton constitute the basis of the food web in most aquatic ecosystems and play a major role in element cycling, productivity, and the regulation of atmospheric $\mathrm{CO}_{2}$ levels ${ }^{1}$. Research efforts developed over the last few decades to understand how microbial plankton respond to warming have focused on large-scale averages across time ${ }^{2}$. However, environmental heterogeneity should be included as a target driver in biological manipulation experiments to obtain more realistic predictions of global warming impacts ${ }^{3,4}$.

\section{Effects of constant warming on aquatic ecosystems and organisms}

Temperature governs all biochemical reactions ${ }^{5}$. Through its effect on metabolic rates, temperature has multiple repercussions on different biological organization levels, from populations to ecosystems ${ }^{6}$. For instance, warming stimulates preferentially heterotrophic versus autotrophic growth because of their higher thermal dependence ${ }^{7}$, and herbivorous protists' growth compared with that of phototrophs ${ }^{8}$. It also promotes changes toward small-size protist communities when nutrients are limiting ${ }^{9}$ and can lead to losses of species richness and evenness in temperate phytoplankton communities ${ }^{10}$. Studies with experimental microbial food webs have shown that warming increases heterotrophic bacteria standing stocks and accelerates viral dynamics ${ }^{11}$, anticipates spring phytoplankton bloom timing, extending its duration ${ }^{12}$, and increases primary productivity $^{13}$ but reduces their carbon sink capacity ${ }^{14}$. Finally, warming can alter the trophic interactions, including those of producer-consumer $^{15,16}$ and host-parasite ${ }^{17}$, and reduce the efficiency of energy transfer to higher trophic levels ${ }^{18}$. Although most investigations have considered the effects of constant in situ or increased temperatures only (Figure 1A), already more than a century ago, Jensen ${ }^{19}$ stated through his famous inequality, also termed the fallacy of the average $^{20}$, that the response of a system to constant average conditions is different from its mean response to variable conditions. Environmental variability can affect the response of communities and ecosystems to global warming through thermal fluctuations above and below mean temperatures, in which variance remains constant (Figure 1B) or is irregular (Figure 1C), and through amplified thermal fluctuations in which the variance increases over time (Figure 1D) or is higher in future respect to present conditions (Figure 1E), thus exposing organisms to more extreme conditions. Because of underlying non-linear relationships, thermal variability can improve or reduce performance

\section{Classical view-constant environment}

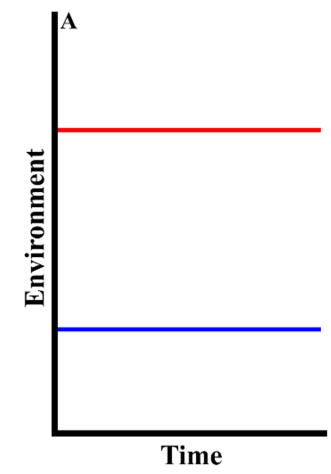

\section{Current view-Fluctuating environment}

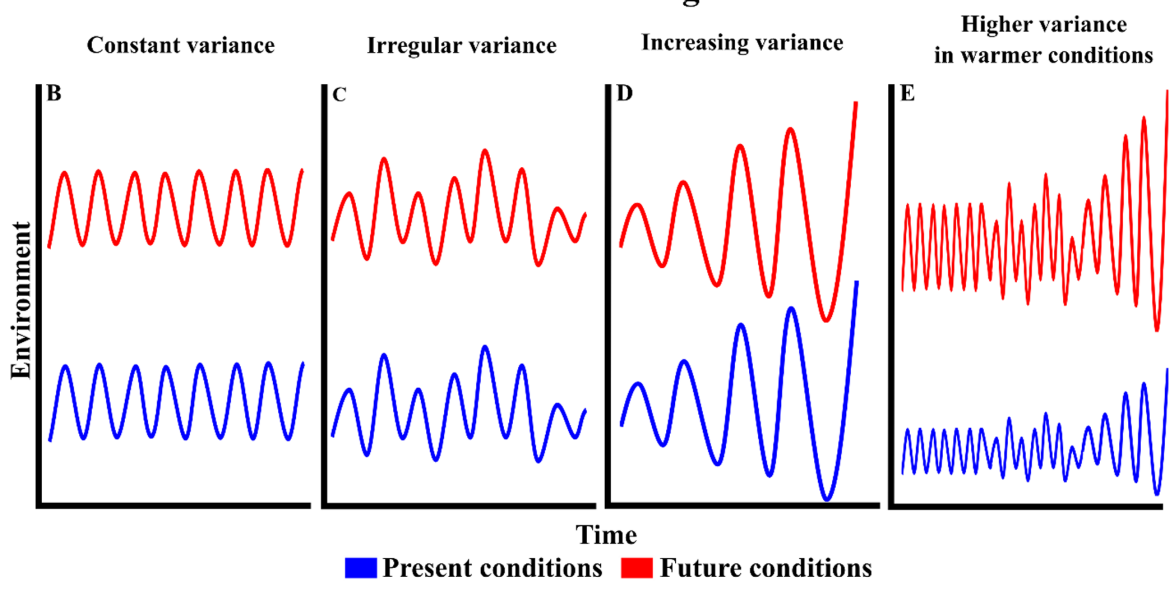

Figure 1. The classical and current view to evaluate the effects of global warming through experimental approaches. 
compared to that predicted by thermal response curves built under constant conditions ${ }^{20,21}$. This prediction is supported by the observation that rate measurements at constant temperatures may overestimate or underestimate those rates occurring in naturally fluctuating environments $\mathrm{s}^{22,23}$.

\section{Effects of fluctuating temperatures on aquatic ecosystems and organisms}

Advances in remote sensing technologies and measurements from instruments anchored to floats, ocean gliders, and ships provide increasing evidence that surface ocean waters are a dynamic thermal environment, with temperatures fluctuating over varying time scales from changing weather, diel cycles, and ocean-atmosphere oscillations ${ }^{24}$. Moreover, these natural fluctuation patterns are being altered by climate change. For example, interannual variance has risen by more than $25 \%$ since 1980 in some areas (e.g. Europe) ${ }^{25}$, mainly due to an increasing occurrence of regional heatwaves since $1950^{26}$. Under this scenario, organisms are already experiencing abrupt shifts in their local temperature environment over short-term (from hours to weeks) and mid-term (seasons) scales rather than changes in climate per se, although long-term changes ultimately drive shorter ones ${ }^{4}$. Doblin and van Sebile ${ }^{27}$ demonstrated that this temperature variability can be up to $10^{\circ} \mathrm{C}$ greater than seasonal fluctuations estimated in a constant environment and that this variability depends strongly on location. Organisms naturally experiencing variations in temperature will tend to be generalists (i.e. highly plastic), having broad thermal breadths, whereas those from "stable" environments will likely be thermal specialists and will be restricted to specific regions/areas ${ }^{28}$. In addition, differences in generation times in populations can promote different adaptive dynamics to highly variable environments. This directional selection seems to be more effective for faster-growing than slower-growing populations because faster-growing microbes experience the "selective" environment for a larger number of generations ${ }^{29}$. These contrasting strategies may allow organisms adapted to fluctuating environments to grow faster, attain higher yield, or use resources more efficiently ${ }^{30,31}$. By contrast, it has also been proposed that increased temperature variation may pose a greater risk to species than the impacts derived from climate warming itself ${ }^{32,33}$. Bernhardt et al. ${ }^{34}$ found that fluctuating temperatures may reduce phytoplankton maximum growth rates by $\sim 20 \%$, their optimal temperature by $\sim 3^{\circ} \mathrm{C}$, and the maximum mean temperatures for positive growth by $2^{\circ} \mathrm{C}$. Qu et $a l .^{35}$ reported reductions in specific nitrogen and carbon fixation rates in the nitrogen fixer Trichodesmium when compared to constant temperature conditions.

Zhang et $a .^{36}$ have shown that increases in thermal variability have anticipated the cyanobacterial bloom initiation by $\sim 80$ days over the last three decades in Lake Taihu. Additionally, these authors have reported that cyanobacterial growth ${ }^{36}$ and photochemical performance ${ }^{37}$ are less sensitive to fluctuating temperatures than those of green algae and diatoms. Fluctuating temperatures can also promote both predator collapse ${ }^{38}$ and species competitive success, potentially facilitating biological invasions $^{39}$, particularly when native species are not adapted to the fluctuating environment considered ${ }^{40}$. The underlying mechanism underpinning such observations is that directional selection on plasticity can also be weak, non-significant, or absent ${ }^{41}$, likely because production and maintenance costs can become too high to cover the increasingly wide environmental gradient that an organism experiences ${ }^{21}$. Therefore, ignoring the effects of environmental variability may limit our ability to predict how organisms are responding to ongoing warming, in particular those living at the edge of their thermal ranges.

\section{Interactions between warming and fluctuating temperature}

Most laboratory investigations evaluating how fluctuating temperatures and warming interact have so far concentrated on a few well-studied species such as the coccolithophore Emiliania huxleyi $i^{42}$ and the diatom Thalassiosira pseudonana ${ }^{43}$. A deeper understanding about how populations respond to these drivers would entail knowing whether such responses can be extrapolated to other phytoplankton groups (e.g. cyanobacteria and dinoflagellates) and to other trophic levels (i.e. decomposers and grazers), even to similar species but with contrasting nutrition modes (i.e. mixotrophs versus strict phototrophs or heterotrophs). At the community level, most of the available evidence has focused on phytoplankton, while more comprehensive investigations at the ecosystem level (e.g. carbon sink capacity) are lacking.

The studies performed have considered either short-term scales (i.e. days), which represent acute/stress responses to the environmental drivers assayed ${ }^{42,44}$, or mid-term scales, that is, those that allow organisms' acclimation ${ }^{43,45,46}$ (Table 1). Evolutionary responses over longer time scales to the interacting effect of warming and fluctuating temperature are still underrepresented ${ }^{47}$; however, it is known that thermal adaptation mediated by trait selection during evolutionary change can reverse short- and mid-term effects of constant warming on metabolic rates ${ }^{48}$.

There seems to be an imbalance between the amount of work conducted in different biomes, with marine ecosystems receiving more attention than freshwater environments. Although the ocean biome covers $>75 \%$ of the Earth's surface and its role in biogeochemical cycling is dominant, freshwater ecosystems, such as lakes and shallow ponds, have characteristics that also make them significant for global budgets. For example, these ecosystems exchange carbon at areal rates that are orders of magnitude greater than virtually any other global ecosystem (i.e. little things mean a lot $)^{49}$.

Results available from experimental studies have been mostly performed in temperate areas (or species) ${ }^{42,44,45,50}$, whereas studies addressing the role of temperature fluctuations on microbial plankton in boreal/polar and tropical areas are scarce. Because thermal variability increases towards the poles ${ }^{51}$ and some high-latitude regions such as the Arctic are warming faster than the global average ${ }^{52}$, it becomes crucial to understand how the interplay between interacting environmental drivers modulates community responses in different biomes. 


\begin{abstract}
Table 1. Qualitative effects of warming (W) and warming under fluctuating temperatures $(\mathrm{W} \times \mathrm{F})$ on microbial plankton properties measured over different biological organization levels, temporal scales, and ecosystems.
\end{abstract}

\begin{tabular}{|c|c|c|c|c|c|}
\hline Biol. Org. Level & Response Variable & W & $W \times F$ & Temporal scale & Ecosystem \\
\hline \multirow{11}{*}{ 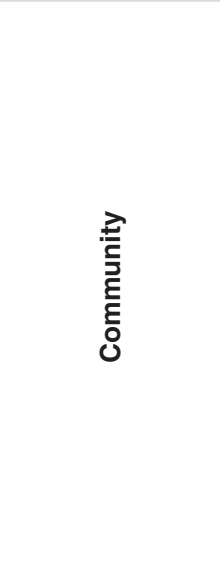 } & Cyanobacteria biomass $^{1}$ & & & \multirow{8}{*}{ Months } & \multirow{8}{*}{ 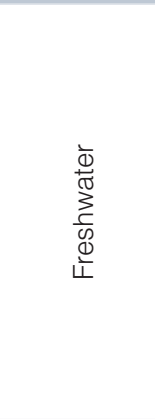 } \\
\hline & Cyanobacteria recruitment ${ }^{1}$ & & & & \\
\hline & Heterotrophic bacteria abundance ${ }^{2}$ & & & & \\
\hline & Phytoplankton abundance $(<20 \mu \mathrm{m})^{2}$ & & & & \\
\hline & Phytoplankton abundance $(20-150 \mu \mathrm{m})^{2}$ & & & & \\
\hline & Phytoplankton evenness ${ }^{2}$ & & & & \\
\hline & Phytoplankton richness ${ }^{2}$ & & & & \\
\hline & Zooplankton:phytoplankton biomass ${ }^{2}$ & & & & \\
\hline & Bsi specific growth rate ${ }^{3}$ & & & \multirow{3}{*}{ Days } & \multirow{3}{*}{$\begin{array}{l}\stackrel{\mathbb{E}}{=} \\
\stackrel{\mathbb{\sigma}}{\sum}\end{array}$} \\
\hline & POC specific growth rate ${ }^{3}$ & & & & \\
\hline & Specific dominance ${ }^{3}$ & & & & \\
\hline \multirow{23}{*}{$\begin{array}{l}\frac{\Omega}{0} \\
\frac{\pi}{3} \\
\frac{0}{0} \\
0\end{array}$} & Bioflim formation ${ }^{5}$ & & & \multirow{15}{*}{ Months } & \multirow{15}{*}{ 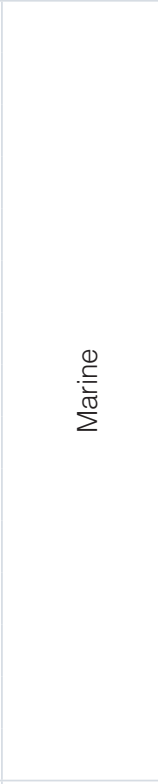 } \\
\hline & Carbon quota ${ }^{4}$ & & & & \\
\hline & Carbon use efficiency ${ }^{4}$ & & & & \\
\hline & Carbon:nitrogen ratio ${ }^{4}$ & & & & \\
\hline & Carbon:phosphorous ratio ${ }^{4}$ & & & & \\
\hline & Cell size ${ }^{4}$ & & & & \\
\hline & Chlorophyll:carbon ratio ${ }^{4}$ & & & & \\
\hline & Gross photosynthesis ${ }^{4}$ & & & & \\
\hline & Nitrogen quota ${ }^{4}$ & & & & \\
\hline & Nitrogen: phosphorous ratio ${ }^{4}$ & & & & \\
\hline & Phosphorous quota ${ }^{4}$ & & & & \\
\hline & Phytoplankton growth ${ }^{5}$ & & & & \\
\hline & Protein content ${ }^{4}$ & & & & \\
\hline & Respiration ${ }^{4}$ & & & & \\
\hline & RNA content ${ }^{4}$ & & & & \\
\hline & Calcification:photosynthesis ${ }^{6}$ & & & \multirow{8}{*}{ Days } & \multirow{8}{*}{$\underset{\substack{\frac{D}{E} \\
\sum}}{\frac{\pi}{2}}$} \\
\hline & Calcification $^{6}$ & & & & \\
\hline & Carbon:chlorophyll ratio ${ }^{6}$ & & & & \\
\hline & Carbon:nitrogen ratio ${ }^{6}$ & & & & \\
\hline & Nitrogen:phosphorus ratio ${ }^{6}$ & & & & \\
\hline & Photosynthesis ${ }^{6}$ & & & & \\
\hline & Phytoplankton growth ${ }^{6}$ & & & & \\
\hline & PIC:POC ration ${ }^{6}$ & & & & \\
\hline
\end{tabular}

Rectangles represent absence of effect (white), negative effect (orange), strongly negative effect (red), positive effect (light green), and strongly positive effect (green). Superscript numbers in response variables represent studies where interactive effects of temperature fluctuations and warming were tested. Sources are ${ }^{1}$ Urrutia-Cordero et al. ${ }^{50}$, ${ }^{2}$ Rasconi et al. ${ }^{45},{ }^{3}$ Kling et al. ${ }^{44},{ }^{4}$ Schaum et al. ${ }^{43},{ }^{5}$ Schaum et al. ${ }^{46}$ and ${ }^{6}$ Wang et al. ${ }^{42}$. Bsi represents biogenic silica, a proxy for diatom-specific rates, and PIC and POC are particulate inorganic and organic carbon, respectively. 
Temperature fluctuations have been shown to accentuate, attenuate, and even reverse the effect of warming on different properties and processes at the population and community level (Table 1). For instance, researchers have found a negative synergistic effect of the warming $\times$ fluctuating temperature interaction on gross photosynthesis ${ }^{43}$ and phytoplankton evenness $^{45}$ but also a positive synergistic effect on microbial biofilm formation and phytoplankton growth ${ }^{46}$. Other reports indicate that temperature fluctuations can attenuate the positive effect of warming on cyanobacterial biomass production and recruitment $^{50}$ or reverse the warming effect on carbon and nitrogen quotas ${ }^{43}$. Absence of effects has also been reported. For example, fluctuation in temperature did not affect species dominance in phytoplankton communities under warming conditions $^{44}$ or alter the stimulatory effect of warming on photosynthetic activity in the coccolithophore E. huxleyi ${ }^{42}$.

The temperature dependence of plankton metabolic rates can be suppressed when nutrients are strongly limiting, hence some of the temperature effects discussed above might be circumscribed to ecosystems with high nutrient supply (e.g. coasts and upwelling systems $)^{53}$. The interaction between nutrient availability and temperature variability is proving relevant to understand the dynamics and trophic functioning of microbial plankton communities. Model simulations and observations in tropical and temperate ecosystems show that phytoplankton blooms during heatwaves are weaker in nutrient-limited ecosystems and stronger when nutrients are $\operatorname{high}^{54}$. Nutrient limitation can weaken the producer-consumer interaction under warming conditions ${ }^{15}$ and increase the thermal range where a species is successful with respect to its competitors ${ }^{55}$.

\section{Future research directions}

Despite the difficulties in testing and understanding how climate change affects microbial food webs because multiple environmental drivers are acting simultaneously ${ }^{56}$, future research efforts should take into account natural variations above and below mean trends in environmental drivers because these fluctuations could increase in frequency and intensity owing to the ongoing global warming. We stress the need to quantify these impacts over different biological organization levels (from molecules to ecosystems), different temporal scales (short versus long term), and types of ecosystems (marine and freshwater) to obtain a more comprehensive understanding of the magnitude and direction of global warming impacts on aquatic ecosystems.
1. Falkowski P, Raven JA: Aquatic Photosynthesis. Princeton University Press. 2013.

Reference Source

2. Doney SC: Oceanography: Plankton in a warmer world. Nature. 2006; 444(7120): 695-6.

PubMed Abstract | Publisher Full Text

3. Schaum CE, Collins S: Plasticity predicts evolution in a marine alga. Proc Biol Sci. 2014; 281(1793): 20141486.

PubMed Abstract | Publisher Full Text | Free Full Text

4. Boyd PW, Cornwall CE, Davison A, et al:: Biological responses to environmental heterogeneity under future ocean conditions. Glob Chang Biol. 2016; 22(8): 2633-50.

PubMed Abstract | Publisher Full Text

5. Gillooly JF, Brown JH, West GB, et al:: Effects of size and temperature on metabolic rate. Science. 2001; 293(5538): 2248-51.

PubMed Abstract | Publisher Full Text | Faculty Opinions Recommendation

6. Brown JH, Gillooly JF, Allen AP, et al:: Toward a metabolic theory of ecology. Ecology. 2004; 85(7): 1771-89. Publisher Full Text

7. López-Urrutia A, San Martin E, Harris RP, et al.: Scaling the metabolic balance of the oceans. Proc Natl Acad Sci U S A. 2006; 103(23): 8739-44. PubMed Abstract | Publisher Full Text | Free Full Text | Faculty Opinions Recommendation

8. Rose JM, Caron DA: Does low temperature constrain the growth rates of heterotrophic protists?: Evidence and implications for algal blooms in cold waters. Limnol Oceanogr. 2007; 52(2): 886-95.

Publisher Full Text

9. Peter $\mathrm{KH}$, Sommer U: Phytoplankton cell size reduction in response to warming mediated by nutrient limitation. PLoS One. 2013; 8(9): e71528. PubMed Abstract | Publisher Full Text | Free Full Text

10. Verbeek L, Gall A, Hillebrand $\mathrm{H}$, et al.: Warming and oligotrophication cause shifts in freshwater phytoplankton communities. Glob Chang Biol. 2018; 24(10): 4532-43.

PubMed Abstract | Publisher Full Text

11. Frenken $\mathrm{T}$, Brussaard CPD, Velthuis $\mathrm{M}$, et al.: Warming advances virus population dynamics in a temperate freshwater plankton community. Limnol Oceanogr. 2020; 5(4): 295-304.

Publisher Full Text
12. Friedland KD, Mouw CB, Asch RG, et al.: Phenology and time series trends of the dominant seasonal phytoplankton bloom across global scales. Global Ecol Biogeogr. 2018; 27(5): 551-69. Publisher Full Text

13. Yvon-Durocher G, Allen AP, Cellamare M, et al:: Five Years of Experimental Warming Increases the Biodiversity and Productivity of Phytoplankton. PLOS Biol. 2015; 13(12): e1002324.

PubMed Abstract | Publisher Full Text | Free Full Text

14. Yvon-Durocher G, Hulatt CJ, Woodward G, et al:: Long-term warming amplifies shifts in the carbon cycle of experimental ponds. Nat Clim Change. 2017; 7(3): 209-13.

Publisher Full Text

15. O'Connor MI, Piehler MF, Leech DM, et al.: Warming and resource availability shift food web structure and metabolism. PLoS Biol. 2009; 7(8): e1000178. PubMed Abstract | Publisher Full Text | Free Full Text

16. Schaum CE, Student Research Team, Ffrench-Constant R, et al:: Temperaturedriven selection on metabolic traits increases the strength of an algal-grazer interaction in naturally warmed streams. Glob Chang Biol. 2018; 24(4): 1793-803.

PubMed Abstract | Publisher Full Text

17. Claar DC, Wood CL: Pulse Heat Stress and Parasitism in a Warming World. Trends Ecol Evol. 2020; 35(8): 704-15. PubMed Abstract | Publisher Full Text

18. Ullah H, Nagelkerken I, Goldenberg SU, et al.: Climate change could drive marine food web collapse through altered trophic flows and cyanobacterial proliferation. PLoS Biol. 2018; 16(1): e2003446. PubMed Abstract | Publisher Full Text | Free Full Text

19. Jensen JLWV: Sur les fonctions convexes et les inégalités entre les valeurs moyennes. Acta Math. 1906; 30: 175-93. Publisher Full Text

20. Denny M: The fallacy of the average: on the ubiquity, utility and continuing novelty of Jensen's inequality. J Exp Biol. 2017; 220(Pt 2): 139-46. PubMed Abstract | Publisher Full Text

21. Kroeker KJ, Bell LE, Donham EM, et al:: Ecological change in dynamic environments: Accounting for temporal environmental variability in studies of ocean change biology. Glob Chang Biol. 2020; 26(1): 54-67. PubMed Abstract | Publisher Full Text | Faculty Opinions Recommendation

22. Montagnes DJS, Weisse T: Fluctuating temperatures affect growth and 
production rates of planktonic ciliates. Aquat Microb Ecol. 2000; 21: 97-102. Publisher Full Text

23. Lawson $C R$, Vindenes $Y$, Bailey $L$, et al.: Environmental variation and population responses to global change. Ecol Lett. 2015; 18(7): 724-36. PubMed Abstract | Publisher Full Text | Faculty Opinions Recommendation

24. Bates AE, Helmuth $\mathrm{B}$, Burrows MT, et al:: Biologists ignore ocean weather at their peril. Nature. 2018; 560(7718): 299-301.

PubMed Abstract | Publisher Full Text

25. IPCC: Global Warming of $1.5^{\circ} \mathbf{C}$. An IPCC Special Report on the impacts of global warming of $1.5^{\circ} \mathrm{C}$ above pre-industrial levels and related global greenhouse gas emission pathways, in the context of strengthening the global response to the threat of climate change, sustainable development, and efforts to eradicate povert. 2019; 630.

Reference Source

26. Perkins-Kirkpatrick SE, Lewis SC: Increasing trends in regional heatwaves. Nat Commun. 2020; 11: 3357

PubMed Abstract | Publisher Full Text | Free Full Text

27. Doblin MA, van Sebille E: Drift in ocean currents impacts intergenerational microbial exposure to temperature. Proc Natl Acad Sci U S A. 2016; 113(20): 5700-5.

PubMed Abstract | Publisher Full Text | Free Full Text

28. Gilchrist GW: Specialists and generalists in changing environments. I. Fitness landscapes of thermal sensitivity. Am Nat. 1995; 146(2): 252-70. Publisher Full Text

29. Walworth NG, Zakem EJ, Dunne JP, et al:: Microbial evolutionary strategies in a dynamic ocean. Proc Natl Acad Sci U S A. 2020; 117(11): 5943-8. PubMed Abstract | Publisher Full Text | Free Full Text

30. Ketola $\mathrm{T}$, Saarinen $\mathrm{K}$ : Experimental evolution in fluctuating environments: Tolerance measurements at constant temperatures incorrectly predict the ability to tolerate fluctuating temperatures. J Evol Biol. 2015; 28(4): 800-6. PubMed Abstract | Publisher Full Text

31. Saarinen K, Laakso J, Lindström L, et al:: Adaptation to fluctuations in temperature by nine species of bacteria. Ecol Evol. 2018; 8(5): 2901-10. PubMed Abstract | Publisher Full Text | Free Full Text

32. Vasseur DA, DeLong JP, Gilbert B, et al:: Increased temperature variation poses a greater risk to species than climate warming. Proc Biol Sci. 2014; 281(1779): 20132612.

PubMed Abstract | Publisher Full Text | Free Full Text

33. Salinas S, Irvine SE, Schertzing CL, et al:: Trait variation in extreme thermal environments under constant and fluctuating temperatures. Philos Trans $R$ Soc Lond B Biol Sci. 2019; 374(1768): 20180177. PubMed Abstract | Publisher Full Text | Free Full Text

34. Bernhardt JR, Sunday JM, Thompson PL, et al:: Nonlinear averaging of thermal experience predicts population growth rates in a thermally variable environment. Proc Biol Sci. 2018; 285(1886): 20181076 PubMed Abstract | Publisher Full Text | Free Full Text

35. Qu P, Fu FX, Kling JD, et al:: Distinct responses of the nitrogen-Fixing marine cyanobacterium Trichodesmium to a thermally variable environment as a function of phosphorus availability. Front Microbiol. 2019; 10: 1282. PubMed Abstract | Publisher Full Text | Free Full Text

36. Zhang M, Qin B, Yu Y, et al:: Effects of temperature fluctuation on the development of cyanobacterial dominance in spring: Implication of future climate change. Hydrobiologia. 2016; 763: 135-46. Publisher Full Text

37. Zhang M, Guan Y, Qin B, et al.: Responses of phytoplankton species to diel temperature fluctuation patterns. Phycological Res. 2019; 67(3): 184-91. Publisher Full Text

38. Dee LE, Okamtoto $D$, Gårdmark $A$, et al:: Temperature variability alters the stability and thresholds for collapse of interacting species. Philos Trans $R$ SoC Lond B Biol Sci. 2020; 375(1814): 20190457.

PubMed Abstract | Publisher Full Text | Free Full Text

39. Räsänen E, Lindström L, Ketola T: Environmental fluctuations drive species' competitive success in experimental invasions. Annales Zoologici Fennici. 2020; 57(1-6): 79 .

Publisher Full Text
40. Saarinen K, Lindström L, Ketola T: Invasion triple trouble: Environmental fluctuations, fluctuation-adapted invaders and fluctuation-mal-adapted communities all govern invasion success. BMC Evol Biol. 2019; 19: 42. Publisher Full Text

41. Arnold PA, Nicotra AB, Kruuk LEB: Sparse evidence for selection on phenotypic plasticity in response to temperature. Philos Trans R Soc Lond B Biol Sci. 2019; 374(1768): 20180185.

PubMed Abstract | Publisher Full Text | Free Full Text

42. Wang X, Fu F, Qu P, etal.: How will the key marine calcifier Emiliania huxley respond to a warmer and more thermally variable ocean? Biogeosciences. 2019; 16: 4393-409. Publisher Full Text

43. Schaum $\mathrm{CE}$, Buckling A, Smirnoff $\mathrm{N}$, et al.: Environmental fluctuations accelerate molecular evolution of thermal tolerance in a marine diatom. Nat Commun. 2018; 9(1): 1719

PubMed Abstract | Publisher Full Text | Free Full Text

44. Kling JD, Lee MD, Fu F, et al.: Transient exposure to novel high temperatures reshapes coastal phytoplankton communities. ISME J. 2020; 14(2): 413-24. PubMed Abstract | Publisher Full Text | Free Full Text

45. Rasconi S, Winter K, Kainz MJ: Temperature increase and fluctuation induce phytoplankton biodiversity loss - Evidence from a multi-seasonal mesocosm experiment. Ecol Evol. 2017; 7(9): 2936-46.

PubMed Abstract | Publisher Full Text | Free Full Text

46. Schaum CE: Enhanced biofilm formation aids adaptation to extreme warming and environmental instability in the diatom Thalassiosira pseudonana and its associated bacteria. Limnol Oceanogr. 2019; 64(2): 441-60. Publisher Full Text

47. Collins S, Boyd PW, Doblin MA: Evolution, Microbes, and Changing Ocean Conditions. Ann Rev Mar Sci. 2020; 12: 181-208. PubMed Abstract | Publisher Full Text

48. Barton S, Jenkins J, Buckling A, et al.: Evolutionary temperature compensation of carbon fixation in marine phytoplankton. Ecol Lett. 2020; 23(4): 722-33. PubMed Abstract | Publisher Full Text | Free Full Text | Faculty Opinions Recommendation

49. Downing J: Emerging global role of small lakes and ponds: Little things mean a lot. Limnetica. 2010; 29(1): 9-24. Publisher Full Text

50. Urrutia-Cordero $\mathrm{P}$, Zhang $\mathrm{H}$, Chaguaceda $\mathrm{F}$, et al:: Climate warming and heat waves alter harmful cyanobacterial blooms along the benthic-pelagic interface. Ecology. 2020; 101(7): e03025. PubMed Abstract| Publisher Full Text

51. Righetti D, Vogt M, Gruber N, et al:: Global pattern of phytoplankton diversity driven by temperature and environmental variability. Sci Adv. 2019; 5(5): eaau6253. PubMed Abstract | Publisher Full Text | Free Full Text

52. Post $\mathrm{E}$, Alley RB, Christensen TR, et al:: The polar regions in a $2^{\circ} \mathrm{C}$ warmer world. Sci Adv. 2019; 5(12): eaaw9883.

PubMed Abstract | Publisher Full Text | Free Full Text

53. Marañón $E$, Lorenzo MP, Cermeño $P$, et al: Nutrient limitation suppresses the temperature dependence of phytoplankton metabolic rates. ISME J.2018; 12(7): 1836-45.

PubMed Abstract | Publisher Full Text | Free Full Text

54. Hayashida H, Matear RJ, Strutton PG: Background nutrient concentration determines phytoplankton bloom response to marine heatwaves. Glob Change Biol. 2020; 26(9): 4800-11.

PubMed Abstract | Publisher Full Text | Faculty Opinions Recommendation

55. Siegel P, Baker KG, Low-Décarie E, et al:: High predictability of direct competition between marine diatoms under different temperatures and nutrient states. Ecol Evol. 2020; 10(14): 7276-90. PubMed Abstract | Publisher Full Text | Free Full Text

56. Vvan de Waal DB, Litchman E: Multiple global change stressor effects on phytoplankton nutrient acquisition in a future ocean. Philos Trans $R$ Soc Lond $B$ Biol Sci. 2020; 375(1798): 20190706.

PubMed Abstract | Publisher Full Text | Free Full Text |

Faculty Opinions Recommendation 